\title{
First Report of the Smut Pathogen on Tef (Eragrostis tef) in Ethiopia
}

\author{
Ashenafi Gemechu Degete \\ Ethiopian Institute of Agricultural Research (EIAR), Debre Zeit Agricultural Research Center, Debre Zeit, Ethiopia \\ Email address: \\ gemechuashenafi@gmail.com

\section{To cite this article:} \\ Ashenafi Gemechu Degete. First Report of the Smut Pathogen on Tef (Eragrostis tef) in Ethiopia. Plant. Vol. 9, No. 3, 2021 , pp. 66-69. \\ doi: $10.11648 /$ j.plant.20210903.14
}

Received: June 29, 2021; Accepted: July 21, 2021; Published: August 5, 2021

\begin{abstract}
Annually both Belg and main seasons survey of tef diseases was done. In each of the 2019 and 2020 the cropping season, survey of tef diseases was done in both short rainy and long rainy seasons. The survey aimed to monitor emerging or new tef disease in major tef growing regions. During the 2019/20 and 2020/21 cropping season survey, new disease was observed in different areas. The survey aimed to collect unusual tef disease samples observed in the field and report the newly recorded disease. The samples from diseased tef varieties were collected and observed under a microscope directly without culturing because the pathogen is obligate. This disease is known to attack the reproductive organ of the tef plant before heading. The infected part of the plant was swollen and was filled with teliospores. The disease was observed on Quncho, Magna, and Boset varieties in Alaba Zone and West Arsi Zone around Negelle Arsi and Shashemene in Southern Nation Nationality and People and Oromia region, respectively. The diagnosis was easily confirmed by planting imbibed and un imbibed seeds of Quncho in a greenhouse. Imbibed seeds with teliospores of smut gave the same signs to the one observed in the field, while signs were not observed in the unimbibed seeds. The spore cells were slightly circular shapes and measure 5-10 $\mu \mathrm{m}$ in diameter was observed. On the basis of these morphological features; the disease was identified as smut. Species-level identification of this pathogen, evaluation of tef genotypes against this disease, distribution of the pathogen and host range identification is future works.
\end{abstract}

Keywords: Eragrostidis Tef, Imbibed, Quncho, Smut, Variety

\section{Introduction}

Tef [Eragrostis tef (Zucc.) Trotter] is an indigenous staple cereal crop of Ethiopia. There is no doubt that tef is a very ancient crop in Ethiopia, where domestication took place before the birth of Christ. Tef is an important cereal crop in Ethiopia. In 2018/19, it was estimated that tef made up to $24.17 \%$ of all the cultivated area in Ethiopia, covering about 3.1 million hectares and grown by 7 million farmers [1]. Tef is grown in almost all regions of the country for home consumption since it is a preferred grain, and for the local market, since it fetches the highest grain price compared with other cereals and is used as a cash crop by farmers. Although the crop is dominantly cultivated as a sole crop, it is also grown as an intercrop or mixed crop, relay crop, or in rotation with several types of crops [6]. Smut spp is the most destructive fungal disease on other cereal crops. The pathogen can infect the productive parts of the plants and the loss is $100 \%$ once the plant is infected by this pathogen at the maturity stage. Smut diseases are caused by the fungi which produce large masses of black spores in the plants they attack [8].

The crop is grown both in Belg (short rainy season) and Meher (long rainy season). The regions in Ethiopia identified as highly suitable for tef production include Gojam and Shewa, which are located in the central highlands of Ethiopia and are also the largest and major tef production areas in the country modern varieties are used as well as traditional landraces and local cultivars. Tef is often considered as a relatively healthy crop since it suffers very little from epidemics of pests including diseases as compared to most other crops grown in the country $[3,5]$. This has, amongst others, been because the crop species being an indigenous ancient crop originated and domesticated in Ethiopia before the Semetic invasion of 4000-1000 BC [7], it has co-evolved with the pathogens and other pests over the millennia of its 
cultivation [4]. Currently, tef production during Belg (short rainy season starting from End of February- End of May) is common in the West Arsi zone of Oromia. During the last few years tef disease survey was done and the status of tef leaf rust was reported [9]. Tef is infected by about 25 fungal diseases and three pathogenic nematodes [11]. The composition of the fungal species suggests that tef is attacked by different species at seed, seedling, vegetative, and reproductive stages as well as stored grain. Recently distribution of tef head smudge (Helminthosporium miyakei Nisikado) disease durining short rainy and main seasons was also reported [10]. This disease was observed on different tef varieties and found in all the surveyed areas. The main purpose of doing survey is that to assess the prevalence and severity of the known diseases which are already recorded on tef crop. Besides, cupturing the newly emerging disease (s) is the main duety of pathologists. Unfortunatly in 2019 and 2020 surveying year's new disease was observed and samples were collected to identify the emerging tef disease in the country.

\section{Materials and Methods}

Tef diseases survey was made during the short rainy season (Belg) and main season (Meher) curried out in major tef growing areas in $2019 / 20$ G.C in the country. At 5 to 10 $\mathrm{km}$ intervals tef fields, which were at heading to maturity stages, were randomily selected and assessed for diseases. In some pocket areas, unusual disease sign was observed on tef varieties Quncho, and Magna around Negelle Arsi and Shashemene twons in West Arsi Zone. This disease was also observed in Halaba Woreda in Halaba Zone, Southern Nation Nationalities and People region (SNNP). In this Woreda, about $5-10 \%$ tef plants were affected within an area of a few hundred square meters from which infected plant samples were collected.
The infected plants had swollen tip and the head does not exert during the heading (Figure 2). A black masses of spores (teliospores) are observed when the swollen tip is broken or dissected. The incidence of the disease was scored by counting the number of infected tef in the quadrant.

The collected spore samples were observed directly under a microscope $10 \times 40$ to identify the spore shape and size. The spores were not grown in a media because the pathogen is an obligate parasite in nature. The identification was done at Debre Zeit Agricultural Research Center in the plant pathology laboratory. The spores similar to that of oat smut were observed. Finally, to confirm the pathogen following Koch's postulate or principles: about 15-20 tef seeds (Quncho), which were collected from diseased tef plants from the fields, were imbibed in water and the teliospores were added. After thirty minutes, the imbibed seeds were planted in pots (15-20 seeds planted/pots) in the greenhouse and unimbibed seeds were also planted as control. The planting was done under room temperature $\left(25^{\circ} \mathrm{C}\right)$ and relative humidity was about $69 \%$.

\section{Results and Discussion}

Currently tef was challenged by different fungal pathogens. During the survey years of 2019 and 2020 infected tef samples were collected (Figure 1a). The infected spikelets contain masses of spores in place of grain (Figure 1a). After completing the survey, the collected samples were observed under the microscope by placing the teliospores on the slide and adding a drop of water on it and covering it by slide cover. The spores slightly circular shape and size of the teliospores were identified (Figure 1b).

Slightly circular shape and size of the spores were identified. Teliospores are small, circular, measuring 5-10 $\mu \mathrm{m}$ in diameter was observed and measured $(10 \times 40)$. Circular teliospores were observed under the microscope (Figure 1b).

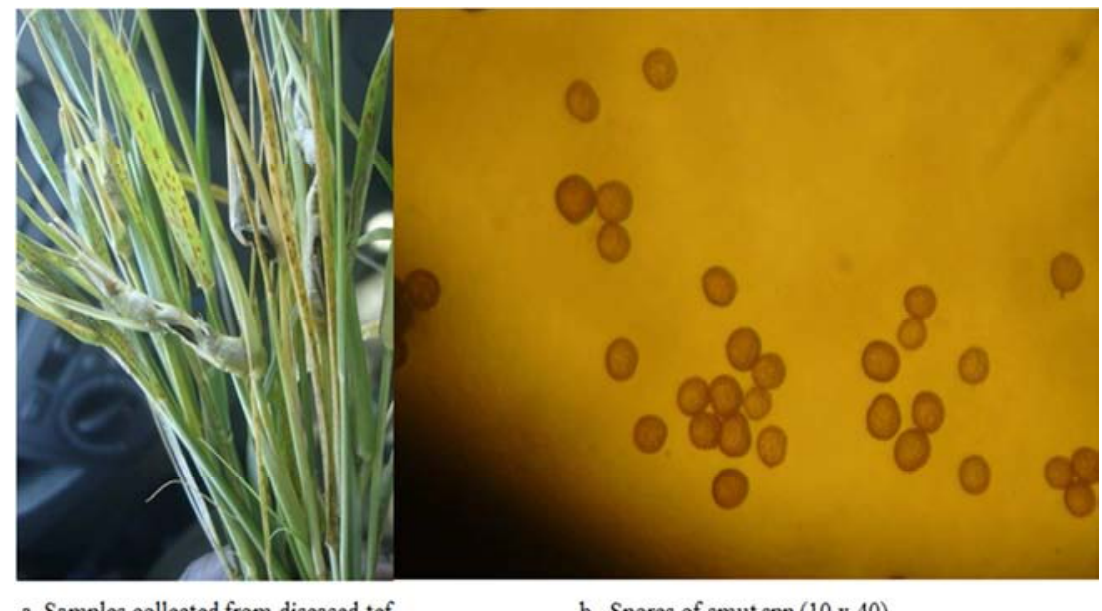

a. Samples collected from diseased tef

b. Spores of smut spp $(10 \times 40)$

Figure 1. Tef diseasesed sample collected from filed and spores.

After identification of the pathogen for further confirmation; tef seeds were planted in the greenhouse. After three months the same signs were observed on the imbibed tef seeds with teliospores and the control or the check was free from the disease. The samples were collected and observed under a microscope and the same result was 
obtained from the imbibed seeds of tef with teliospores.

Teliospores are small, circular, measuring $5-10 \mu \mathrm{m}$ in diameter (Figure 3).

Abundant teliospores were re-isolated from infected tef from the greenhouse (Figure 2), thereby fulfilling Koch's postulates and the same results were observed on the inoculated tef plants.

The inoculation experiments were repeated twice and the same results were obtained. Controls were sprayed with a $0.25 \%$ gelatin suspension and no disease symptom observed (Figure 4).

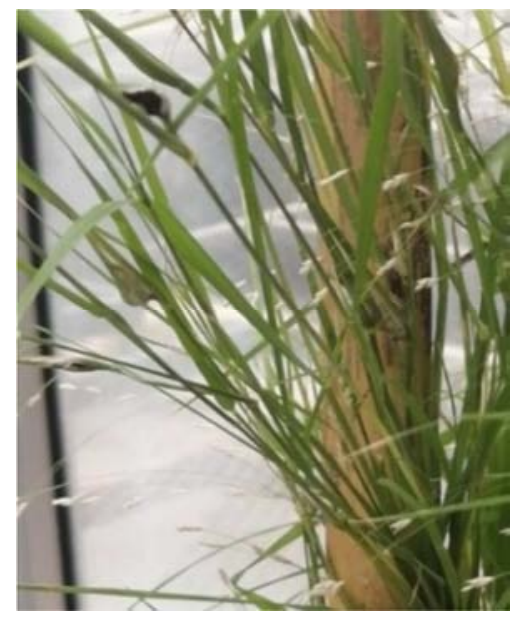

Figure 2. Disease observed in the greenhouse.

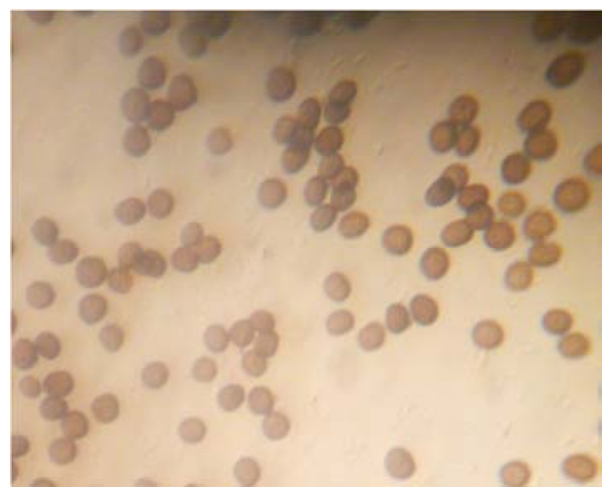

Figure 3. Spores observed from samples collected from greenhouse.

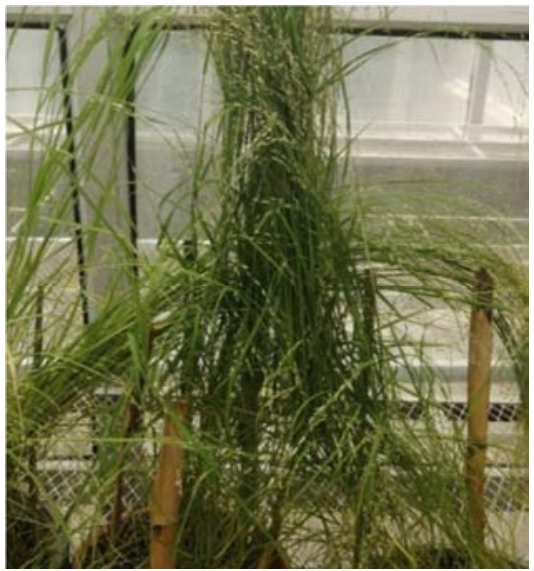

Figure 4. The check/ Control.

\section{Conclusion}

The diagnosis was easily confirmed by planting imbibed and un imbibed seeds of Quncho in a greenhouse. Imbibed seeds with teliospores of smut gave the same signs to the one observed in the field, while signs were not observed in the unimbibed seeds (control). Based on the greenhouse result the pathogen was smut. Species-level identification of this pathogen, evaluation of tef genotypes against this disease, distribution of the pathogen and host range identification are future works.

\section{Acknowledgements}

I would like to offer a great thanks to Ethiopian Institute of Agricultural Research (EIAR) and tef research team of Debre Zeit Agricultural Research Center for their valuable encouragement and technical support during the whole period of the study.

\section{References}

[1] (Central Statistical Agency) (2018/19) Agricultural Sample Survey. Report on Area and Production of Major Crops. Statistical Bulletin 584, Vol. 1, Addis Ababa, Ethiopia.

[2] Assefa, K., and Chanyalew, S. 2018. Agronomics of tef, In: The Economics of Tef, Exploring Ethiopia's Biggest Cash Crop (B. Minten, A. S. Taffesse and P. Brown, eds.), International Food Policy Research Institute (IFPRI), Washington, DC, pp 39-70.

[3] Assefa, K., Yu, J. K., Zeid, M., Belay, G., Tefera, H. and Sorrells, M. E. 2011. Breeding tef [Eragrostis tef (Zucc.) trotter]: conventional and molecular approaches. Plant Breeding 130 (1): 1-9.

[4] Badebo, A. 2013. Pathological research in tef, In: Assefa, K., Chanyalew, S. and Tadele, Z. (eds). Achievements and Prospects of Tef Improvement. Proceedings of the Second International Workshop, November 7-9, 2011, Debre Zeit, Ethiopia. Ethiopian Institute of Agricultural Research, Addis Ababa, Ethiopia; Institute of Plant Sciences, University of Bern, Switzerland. Printed at Stämpfli AG, 3001 Bern, Switzerland, pp 171-192.

[5] Chanyalew, S., Ferede, S. Damte, T., Fikre, T. Genet, Y., Kebede, W., Tolossa, K. and Assefa, K. 2019. Significance and prospects of an orphan crop tef, Planta, An International Journal of Biology250: 753-767, DOI: 10.1007/s00425-01903209-z.

[6] Hundera, F., Bogale, T,, Tefera, H., Assefa, K. and Kefyalew, T.. 2001. Agronomy Research in Tef,. In: Tefera, H., Belay, G. abd Sorrells, M. (eds.), Narrowing the Rift: Tef Research and Development, Proceedings of the International Workshop on Tef Geneticsand Improvement, Ethiopian Agricultural Research Organization, Addis Ababa, Ethiopia, pp: 167-176.

[7] Ponti, J. 1978. The systematics of Eragrostis tef (Gramineae) and related species, $\mathrm{PhD}$ Thesis, University of London. UKAmogne, S. 2004. Host range of tef rust (Uromyces eragrostidis). Tropical Science 44: 177-179. 
[8] Denis Balliger and Trevor Bretag. 1995. Smut diseases of cereal crop. AG0401. ISSN 1329-8062.

[9] Gemechu, A., Assefa, K., Genet, Y., and Fikre, Ts., Status of Tef (Eragrostis tef) Diseases in Ethiopia. Agri Res \& Tech: Open Access J. 2018; 17 (3): 556026. DOI: 10.19080/ARTOAJ.2018.17.556026.

[10] Ashenafi G D. Distribution of Head Smudge (Helminthosporium miyakei) of Tef disease During Short
Rainy and Main Cropping Seasons in Some Parts of Oromia and Southern Nation Nationality and People Regions of Ethiopia. $2021 \quad-4$ (1) OAJBS. ID. 000289. DOI: 10.38125/OAJBS.000289.

[11] Bekele, E. 1986. A review of research on diseases of barley, tef and wheat in Ethiopia. In: Proceedings of the First Ethiopian Crop Protection Symposium. 4-7 February 1985, Addis Ababa, Ethiopia. Institute of Agricultural Research, Addis Ababa, Ethiopia. p. 79. 